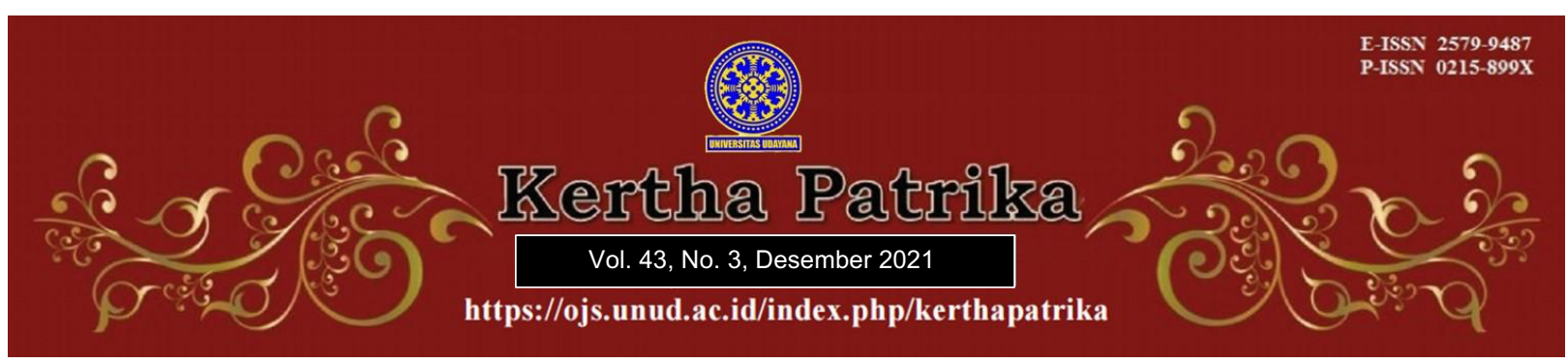

\title{
Urgensi Mediasi sebagai Alternatif Penyelesaian Sengketa Hak Cipta
}

\section{Chrisna Bagus Edhita Praja, ${ }^{1}$ Budi Agus Riswandi, ${ }^{2}$ Khudzaifah Dimyati ${ }^{3}$}

${ }^{1}$ Fakultas Hukum, Universitas Muhammadiyah Magelang, Email: chrisnabagus@ummgl.ac.id

2 Fakultas Hukum, Universitas Islam Indonesia, Email: budiagusr@uii.ac.id

3 Fakultas Hukum, Universitas Muhammadiyah Surakarta, Email: kd255@ums.ac.id

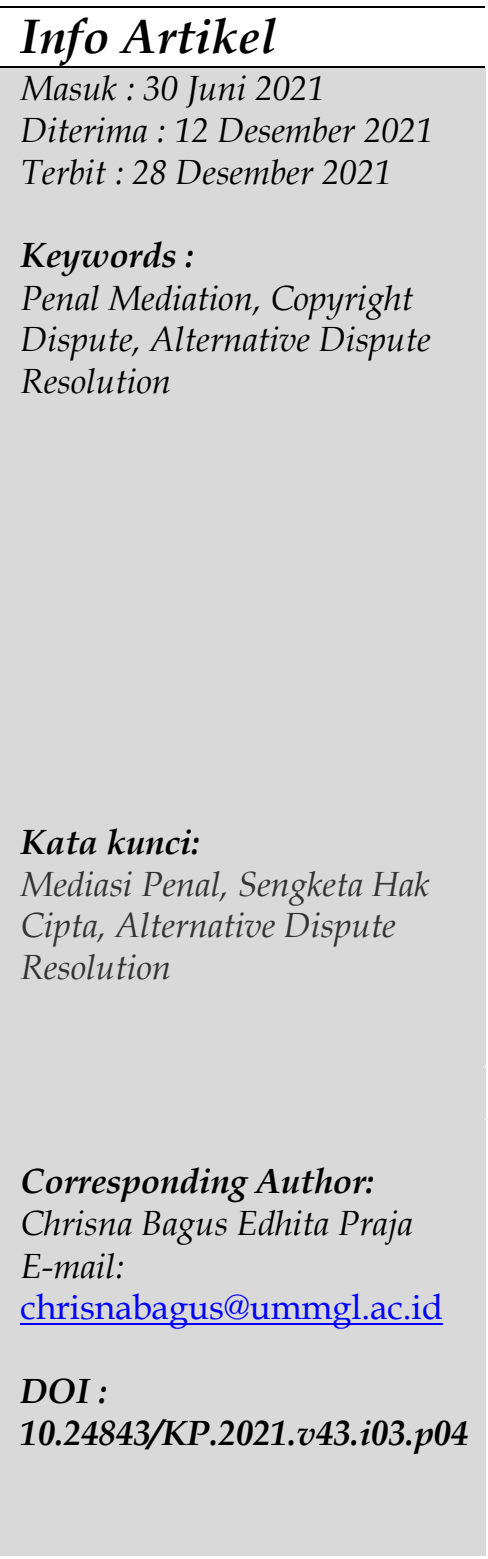

\begin{abstract}
This study aimed to describe the importance of mediation in the copyright dispute resolution. This research used normative juridical research with a statute approach and conceptual approach. The result indicated that several factors are considered for selecting mediation in copyright disputes. These factors are including the follwong: the litigation process that costs a lot of money; Mediation is an alternative solution for sharing copyrights; Mediation as a means of building a business network and reputation; Difficulty in proving in copyright disputes;) The will of Pancasila in dispute resolution amicably; litigation may damage the business relationship or reputation of the parties; and Mediation eases the work of procedural law. Several concepts that must be developed for successful mediation are First, a reliable mediator in settlement of Copyright disputes considering the complexity of copyright law arrangements. Next, the harmonization of Perma Number 1 of 2016 concerning Mediation Procedures in Court with the Copyright Law by synchronizing exceptions to mediation obligations in the Commercial Court with mediation obligations in the Copyright Law. Lastly, the Mediation Process must be informal so that the parties feel comfortable. The implication of this informal process is the establishment of a network and business reputation of the parties.
\end{abstract}

\footnotetext{
Abstrak

Penelitian ini bertujuan untuk mendeskripsikan pentingnya mediasi dalam penyelesaian sengketa Hak Cipta. Penelitian ini menggunakan jenis penelitian yuridis normatif dengan pendekatan (statute approach) dan (conceptual approach). Hasil penelitian menunjukan ada beberapa faktor yang patut untuk dipertimbangkan sebagai alasan memilih mediasi dalam sengketa Hak Cipta. Faktor tersebut adalah 1) Proses litigasi yang memakan biaya yang tinggi (2) Mediasi merupakan solusi alternatif berbagi hak cipta (3) Mediasi sebagai sarana membangun jejaring dan reputasi Bisnis (4) Sulitnya
} 
pembuktian dalam sengketa Hak Cipta (5) Kehendak Pancasila dalam penyelesaian pertikaian secara damai (5) litigasi dapat merusak hubungan bisnis atau reputasi para pihak; (6) Mediasi memperingan kerja hukum acara; (7) Mediasi sebagai budaya hukum di Indonesia. Beberapa konsep yang harus dikembangkan untuk keberhasilan mediasi yaitu Pertama, seorang mediator yang handal dalam penyelesaian sengketa Hak Cipta mengingat kompleksitas pengaturan hukum hak cipta. Kedua, Harmonisasi Perma Nomor 1 tahun 2016 Tentang Prosedur Mediasi Di Pengadilan dengan UU Hak Cipta dengan mensinkronkan pengecualian kewajiban mediasi di Pengadilan Niaga dengan kewajiban mediasi dalam UU Hak Cipta. Ketiga, Proses Mediasi harus bersifat informal agar para pihak yang terlibat merasa saling di hargai dan tidak ada ketegangan yang memacu amarah. Implikasi dari proses informal ini adalah terbangunnya jejaring dan reputasi bisnis para pihak.

\section{Pendahuluan}

Pada tahun 2016, United States Trade Representative (USTR) menyatakan bahwa Indonesia dikategorikan sebagai 4 (empat) negara dengan tingkat pelanggaran Hak Cipta tertinggi di dunia sehingga menjadi priority watch list di tahun 2017. ${ }^{1}$ Selain itu, Global Intellectual Property Center (GIPC) juga menyatakan indeks perlindungan Hak Kekayaan Intelektual (HKI) di Indonesia dianggap masih lemah karena menempati peringkat 33 dari 38 negara. ${ }^{2}$ Kedua data tersebut diperburuk dengan temuan dari Political and Economic Risk Consultancy (PERC) yang menyebutkan bahwa Indonesia merupakan negara pelanggar HKI terburuk di Asia dan penegakan hukumnya dinilai sangat lemah. ${ }^{3}$

Kondisi meningkatnya pelanggaran hak cipta di Indonesia diprediksi terus mengalami kenaikan, terutama di tengah era teknologi informasi seperti saat ini dimana upaya untuk membagikan, menggandakan dan juga mendistribusikan produk hak cipta melalui jaringan internet sangat mudah sehingga berpotensi menambah angka pelanggaran hak cipta. ${ }^{4}$ Sedangkan, tren permohonan pencatatan Hak Cipta di Indonesia sampai dengan tahun 2019 menunjukkan peningkatan yang signifikan sebesar 48.069 permohonan. ${ }^{5}$

Berdasarkan data pelanggaran hak cipta di tengah tren kenaikan permohonan hak cipta di Indonesia, pemerintah Indonesia sudah berupaya menurunkan tingkat pelanggaran Hak Cipta di Indonesia melalui berbagai regulasi, salah satunya adalah menerbitkan Undang - Undang Nomor 28 tahun 2014 tentang Hak Cipta (UU Hak Cipta) sebagai pengganti Undang - Undang Nomor 19 tahun 2002, dimana dalam undang-undang tersebut ditulis mengenai mekanisme penyelesaian sengketa Hak

1 USTR. (2017). 2017 Special 301 Report. https://ustr.gov/sites/default/files/301/2017 \%20Special\%20301\%20Report\%20FINAL.PDF.

2 Sindo, "Indonesia Lemah Soal Perlindungan Kekayaan Intelektual," SINDO, 2016.

3 BBC. (2010). RI pelanggar terburuk HKI di Asia. BBC.

4 Nugrahani, R. A. G. (2018). Pelanggaran Hak Cipta Sebagai Dampak Perkembangan Teknologi. Hukum Pidana dan Pembangunan Hukum, 1(1), 1-6.

5 DJKI. (2019). Permohonan dan Pelindungan HKI di Indonesia 2015-2019. 
Cipta yang terdiri dari litigasi dan non litigasi. Mekanisme penyelesaian sengketa dalam UU Hak Cipta diprediksi dapat memberikan kepastian hukum bagi pemegang hak cipta apabila terdapat upaya pelanggaran hak cipta yang menimbulkan kerugian. Amanat dari UU Hak Cipta mengenai upaya penyelesaian sengketa pelanggaran hak cipta tersebut adalah salah satu upaya negara untuk melindungi hak ekonomi dan hak moral pencipta sebagai salah satu upaya pembangunan kreatifitas nasional. Pelanggaran hak cipta baik hak ekonomi maupun hak moral dikhawatirkan akan mengikis semangat kreatifitas yang pada akhirnya akan berdampak pada menurunnya mikro ekonomi nasional.

Apabila diperhatikan, upaya penyelesaian sengketa lebih dominan pada upaya yang mengarah ke jalur litigasi yang dianggap oleh sebagian masyarakat Indonesia sebagai satu cara untuk menyelesaikan permasalahan hukum. Namun demikian, kasus sengketa HKI yang diselesaikan melalui pengadilan tidak tuntas yang diakibatkan oleh menumpuknya kasus di Pengadilan. Kondisi tersebut berdampak buruk pada para pihak yang bersengketa karena tidak terpenuhinya win win solution. Selain itu, penyelesaian sengketa melalui litigasi cenderung menghabiskan waktu yang lama, ${ }^{6}$ sehingga menimbulkan ketidakpuasan (dissatification) para pihak dan terkesan berteletele (zwaarwichtig), yang akhirnya memunculkan penyelesaian sengketa alternatif (Alternative Dispute Resolution/ADR). ${ }^{7}$

ADR berasal dari Amerika Serikat yang dikembangkan sebagai respon atas peningkatan rasa ketidakpuasan masyarakat dengan sistem peradilan di Amerika. Ketidakpuasan ini muncul dari fakta bahwa proses litigasi akan memakan banyak waktu dan uang untuk diselesaikan, serta kapasitasnya dalam memuaskan para pihak sangat dipertanyakan. Secara filosofis, ADR diciptakan oleh praktisi hukum dan akademisi untuk memfasilitasi penyelesaian konflik sekaligus meningkatkan akses pada keadilan. ${ }^{8}$

ADR atau di Indonesia lebih dikenal dengan istilah Alternatif Penyelesaian Sengketa (APS) diatur dalam Undang-Undang Nomor 30 Tahun 1999 tentang Arbitrase. APS merupakan salah satu upaya untuk mewujudkan keadilan di Indonesia. Sebagai negara yang berlandaskan Pancasila, keadilan merupakan aspek penting terhadap kehidupan masyarakat Indonesia terkait dengan permasalahan hukum.

APS sendiri merupakan salah satu pengejewantahan dari musyawarah mufakat untuk tercapainya solusi terbaik karena hakikatnya penyelesaian sengketa melalui APS untuk menghindari perpecahan dengan tetap menemukan solusi terbaik. Atas dasar problem yang terjadi, Mahkamah Agung pada akhirnya menerbitkan Perma Nomor 1 Tahun 2016 tentang Prosedur Mediasi di Pengadilan menggantikan Peraturan Mahkamah Agung Nomor 1 Tahun 2008. PERMA tersebut mengubah mediasi menjadi

6 Kurniawaty, Y. (2017). Efektivitas Alternatif Penyelesaian Sengketa (Alternative Dispute Resolution on Intellectual Property Dispute). Jurnal Legislasi Indonesia, 14(2), 163-170. doi: https://doi.org/10.54629/jli.v14i2.98

7 Ibid.

8 Taufikkurahman. (2015). Alternative Dispute Resolution dalam Penyelesaian Sengketa Konsumen. Iqtishadia, 2(1), 22-43. doi: https:// doi.org/10.19105/iqtishadia.v2i1.837. 
upaya penyelesaian sengketa yang wajib untuk ditempuh oleh para pihak dalam sebuah gugatan perdata. ${ }^{9}$

Dalam kaitannya dengan penyelesaian sengketa hak cipta, secara yuridis terdapat perbedaan yang signifikan dalam ketentuan penyelesaian sengketa alternatif antara UU Hak Cipta baru dan UU Hak Cipta lama. Dalam UU Hak Cipta lama, para pihak dibebaskan untuk memilih mekanisme penyelesaian sengketa baik secara litigasi maupun non litigasi. Namun, setelah terbit UU Hak Cipta baru dalam Pasal 95(4) para pihak wajib menyelesaikan sengketa Hak Cipta melalui alternatif penyelesaian sengketa sebelum melakukan tuntutan pidana. Dalam prakteknya menurut praktisi di bidang HKI mengatakan bahwa putusan hakim jarang bertentangan satu sama lain meskipun kasusnya sama. Atas permasalahan tersebut muncul sebuah kebingungan terkait putusan mana yang akan dijadikan acuan. Hal itu menunjukkan hukum belum berjalan dengan baik. Meskipun proses berperkara di Pengadilan murah namun apabila ke tingkat kasasi dan peninjauan kembali akan mahal. Peradilan yang selama ini bersifat terbuka dalam sengketa bisnis akan memberikan citra buruk dalam dunia bisnis. ${ }^{10}$ Penelitian yang dilakukan Dewa Gede Yudi Putra Wibawa menjelaskan dalam pengaturan Pasal 95 penyelesaian sengketa pelanggaran Hak Cipta dalam ranah hukum perdata dapat diselesaikan melalui Alternatif Penyelesaian Sengketa, Arbitrase, dan Pengadilan Niaga. ${ }^{11}$ Dalam penelitian Yuniar Kurniawaty menjelaskan Penyelesaian sengketa hak kekayaan intelektual (HKI) dinilai lebih baik melalui jalur nonlitigasi atau melalui lembaga mediasi karena lebih cepat dan biaya murah ${ }^{12}$. Jika menelisik pentingnya mediasi dalam penyelesaian sengketa HKI maka artikel ini akan menyajikan alasan- alasan penting dan implikasi penegakan hukum tindak pidana hak cipta melalui mediasi.

\section{Metode Penelitian}

Jenis penelitian yang digunakan dalam penelitian ini adalah penelitian yuridis normatif dengan menggunakan pendekatan perundang-undangan (statute approach) dan pendekatan konseptual (conceptual approach). Bahan hukum yang digunakan terdiri dari bahan hukum primer dan sekunder. Bahan hukum primer terdiri dari Undang-Undang No 28 Tahun 2014 tentang Hak Cipta dan Peraturan Mahkamah Agung Nomor 1 Tahun 2016 tentang Prosedur Mediasi di Pengadilan. Adapun bahan hukum sekunder yang digunakan yaitu jurnal hukum, buku - buku hukum, maupun artikel di website yang relevan dengan topik yang diteliti.

9 A.Haryo Yudanto, SH, MH, B. (2018). Memberdayakan Mediasi: Musyawarah untuk Mufakat. https://jdih.bappenas.go.id/data/file/Memberdayakan_Mediasi_musyawarah_mufakat.pd f.

10 Pro Kontra Pembentukan Arbitrase Dan Mediasi HKI. https://www.hukumonline.com/berita/baca/lt4c05244b2baae/pro-kontra-pembentukanarbitrase-dan-mediasi-hki/

11 Wibawa, D. G. Y. P., \& Krisnawati, I. G. A. A. A. (2019). Upaya Mediasi Dalam Penyelesaian Sengketa Pelanggaran Hak Cipta. Jurnal Kertha Wicara, Fakultas Hukum Universitas Udayana, 8(01).1-15. https://ocs.unud.ac.id/index.php/kerthawicara/article/download/ $45751 / 27761$

12 Kurniawaty, Y. Op.Cit., 163-170. 


\section{Hasil Dan Pembahasan}

\subsection{Aspek Fundamental Hukum Hak Cipta}

UU hak cipta memberikan hak kepada pencipta berupa hak eksklusif dan independen, termasuk hak untuk mereproduksi karya, untuk membuat karya turunan, dan untuk mempertunjukkan ciptaan. Pencipta memiliki hak untuk mempertahankan dan mengecualikan orang lain dari pelaksanaan hak tersebut, namun dapat menetapkan atau melisensikan kepada orang lain salah satu hak secara independen. Pelaksanaan yang melanggar hukum atas hak semacam itu memungkinkan pemilik hak cipta untuk menuntut ganti atas kerugian yang ditimbulkan dari pelaksanaan hak tersebut.

Pemilik hak cipta yang menggunakan haknya untuk menuntut atas pelanggaran wajib membuktikan kepemilikan hak cipta yang sah dalam karya tersebut dan pembuktian terhadap praktik yang tidak sah atas hak eksklusif yang dimilikinya. Hal tersebut kemudian menimbulkan permasalahan yakni mengenai bagaimana mekanisme pembuktian pelanggaran hak cipta, karena biasanya perselisihan hak cipta melibatkan masalah apakah pihak tertuduh melanggar hak cipta atau tidak. Permasalahan utama dalam perselisihan tersebut terkait dengan tuduhan secara tidak sah terhadap tindakan pengambilan atau penyalinan karya orang lain yang dilindungi hak cipta tidak memiliki indikasi yang jelas. Seringkali, pencipta kesulitan untuk dapat membuktikan kepemilikan tersebut dengan kriteria keaslian (originality) pencipta dan alasan penggunaan yang wajar (fair use) dari tergugat.

Adapun pengaturan tentang fair use di Indonesia, tercantum dalam Pasal 43 sampai dengan Pasal 49 UUHC. Menurut Sudjana, ketentuan fair use di Indonesia tidak jelas batasannya sehingga perlu penafsiran lebih lanjut. ${ }^{13}$ Doktrin fair use dijuluki "doktrin yang paling sulit dalam hukum hak cipta karena merupakan sebuah prinsip yang samar dan menghambat kreativitas yang dirancang oleh hukum untuk dikembangkan. Dalam kasus-kasus tertentu, Konvensi Berne memberi wewenang melalui perundangundangan nasional dalam mengizinkan perlindungan suatu reproduksi, dengan memenuhi 2 (dua) syarat khusus, yaitu: (a) reproduksi tidak bertentangan dengan penggunaan suatu ciptaan; dan (b) reproduksi apa pun tidak menyebabkan hilangnya legitimasi penulis secara wajar. ${ }^{14}$

Sebagai komparasi, Amerika Serikat memperjelas doktrin fair use dengan menuangkannya dalam 17 U.S.C. § 107 dengan parameter (1) tidak diperuntukan untuk sarana komersial, (2) tidak mengubah sifat dari hak cipta itu sendiri, (3) jumlah yang digunakan, dan (4) tidak mempengaruhi pasar dari hak cipta itu sendiri. Namun demikian, doktrin fair use juga seringkali digunakan sebagai alat untuk mempertahankan argumentasi bahwa ciptaan tersebut memiliki keaslian dengan

13 Sudjana, S. (2018). Implikasi Doktrin "Fair Use" Terhadap Pengembangan Ilmu Pengetahuan Oleh Akademisi (Dosen) Atau Peneliti Dalam Perspektif Hukum Hak Cipta. Veritas et Justitia, 4(2), 493-514. doi: https:// doi.org/10.25123/vej.2993.

14 Dwirachma, F., \& Prastyo, B. A. (2015). Analisis Yuridis terhadap Sengketa Hak Cipta Film Soekarno (Issue 1). Universitas Indonesia. 
menambahkan sedikit materi pada Ciptaan aslinya sebagaimana diungkapkan oleh Leval dalam Bunker. ${ }^{15}$

...the secondary use adds value to the original -if the quoted material is used as raw material, transformed in the creation of new information, new aesthetics, new insights, or understandings - this is the very type of activity that the fair use doctrine intends to protect for the enrichment of society.

Fair use kemudian menjadi salah satu hal yang krusial dalam proses pembuktian dalam sengketa hak cipta yang menyulitkan hakim memberikan putusan. ${ }^{16}$ Kondisi ini akhirnya mengakibatkan pihak yang berperkara membutuhkan waktu yang lama dalam mendapatkan kepastian hukum. Menurut Netty Herawati, semakin lama waktu yang dibutuhkan dalam penyelesaian sengketa, maka para pihak membutuhkan biaya yang besar. ${ }^{17}$

Munculnya sengketa tidak bisa lepas dari bentuk pelanggaaran-pelanggaran Hak Cipta itu sendiri. Adapun pelanggaran hak cipta diatur dalam UUHC yang termuat pada Pasal 9, 12, 23, 24, 25, 40, 44, 45, 46, 49, dan Pasal 50 berupa tindakan-tindakan sebagai berikut:

a. Melakukan penggunaan ciptaan secara komersial tanpa hak;

b. Melakukan pelanggaran hak ekonomi suatu ciptaan secara komersial atas tanpa hak;

c. Membajak suatu ciptaan;

d. Dengan sengaja melakukan pembiaran penjualan atau penggandaan barang hasil pelanggaran dan/atau penggandaan hasil pelanggaran Hak Cipta dan/atau Hak terkait di tempat perdagangan yang dikelolanya;

e. Melakukan penggunaan secara komersial, penggandaan, pengumuman, pendistribusian, atau komunikasi atas potret untuk kepentingan reklame atau periklanan untuk penggunaan secara komersial baik dalam media elektronik maupun non elektronik tanpa persetujuan dari orang yang dipotret atau ahli warisnya;

f. Lembaga Manajemen Kolektif yang menarik royalti tanpa izin operasional Menteri

Komar Kantaatmaja berpendapat bahwa penyelesaian sengketa atas pelanggaran hak cipta dapat digolongkan ke dalam tiga jenis yakni: ${ }^{18}$

a. Penyelesaian sengketa berupa negosiasi langsung (negotiation simplisiter) atau dengan pernyataan pihak ketiga (mediasi dan rekonsiliasi);

b. Penyelesaian sengketa litigasi nasional atau internasional;

c. Penyelesaian sengketa melalui arbitrase ad hoc atau terlembaga.

15 Bunker, M. D., \& Erickson, E. (2019). Transformative Variations: The Uses and Abuses of The Transformative Use Doctrine in Right of Publicity Law. Washington Journal of Law, Technology $\mathcal{E}$ Art, 14(2), 139-159.

16 Rosenblatt, E. (2019). Fair Use As Resistance. SSRN Electronic Journal, 9(2), 377-400. doi: https://doi.org/10.2139/ssrn.3348551.

17 Herawati, N. (2011). Implikasi Mediasi Dalam Perkara Perdata Di Pengadilan Negeri Terhadap Asas Peradilan Sederhana, Cepat, Dan Biaya Ringan. Perspektif, 16(4), 227-235. doi: http://dx.doi.org/10.30742/perspektif.v16i4.85

18 Kurniawaty, Y. Op.Cit., 163-170. 
UUHC mengkategorikan pelanggaran hak cipta sebagai tindak pidana dengan delik aduan sebagaimana di atur dalam Pasal 112-119. Namun atas pelanggaran hak cipta yang terjadi, Pasal 95 (4) UUHC juga mengatur proses penyelesaiannya melalui mediasi kecuali pelanggaran dalam bentuk pembajakan. Awal mulanya, mediasi ditujukan hanya untuk penyelesaian sengketa dagang, namun dalam perkembangannya, penerapan mediasi juga dapat digunakan untuk menyelesaikan sengketa perdata dan HKI berupa sengketa paten, merek, hak cipta dapat diselesaikan melalui mediasi.

Salah satu bentuk penyelesaian tindak pidana dapat dilakukan dengan pendekatan non penal. Menurut Wirjono Prodjodikoro, tindak pidana (Strafbaar feit/delik) diartikan sebagai sebuah perbuatan yang dapat dijatuhkan sanksi pidana kepada pelakunya, sehingga pelakunya diistilahkan sebagai subjek tindak pidana. Pembuat undangundang menggunakan istilah perbuatan pidana, tindak pidana, dan peristiwa pidana. Untuk mencapai keadilan dan ketenteraman masyarakat, diperlukan penegakan hukum atas tindak pidana. Menurut Satjipto Raharjo, penegakan hukum adalah suatu proses untuk mewujudkan keinginan-keinginan hukum berupa pikiranpikiran badan pembuat Undang-Undang yang dirumuskan dalam peraturan hukum menjadi kenyataan. ${ }^{19}$ Menurut Sudikno Mertokusumo ada tiga unsur yang perlu diperhatikan dalam penegakan hukum yaitu kepastian hukum, kemanfaatan dan keadilan. ${ }^{20}$ Penegakan hukum dengan pemberian sanksi pidana seringkali menimbukan efek negatif berupa: ${ }^{21}$

a. Dehumanisasi pelaku tindak pidana

b. Prisonisasi

c. A Place of contamination

d. Pidana berjangka pendek

e. Stigmatization

Dari dampak tersebut, Penegak Hukum di Indonesia mulai mengembangkan konsep restorative justice. Gagasan ini mendorong para pelaku untuk memperbaiki kerugian yang mereka timbulkan terhadap korban, keluarga, dan masyarakat. Konsep ini berfungsi sebagai " a meeting place for people " untuk mencari jalan keluar guna memperbaiki hubungan dan kerusakan yang diakibatkan oleh suatu tindak pidana. Keadilan restoratif, menurut Bagir Manan, merupakan reorganisasi sistem peradilan pidana yang lebih adil bagi pelaku, korban, dan masyarakat. Konsep Restorative Justice memiliki 3 (tiga) prinsip dasar, yaitu:

a. Recovery bagi mereka yang mengalami kerugian;

b. Pelaku berkesempatan untuk memulihkan keadaan (restorasi);

c. Pengadilan dan masyarakat memiliki peranan dalam menjaga ketertiban umum dan perdamaian.

19 Raharjo, S. (1983). Masalah Penegakan Hukum. Bandung: Sinar Baru.

20 Sulardi, \& Wardoyo, Y. P. (2015). Kepastian Hukum, Kemanfaatan, dan Keadilan terhadap Perkara Pidana Anak (Kajian Putusan Nomor 201/Pid.Sus/2014/PN.Blt). Jurnal Yudisial, 8(3), 251-268. doi: https:// doi.org/10.1017/CBO9781107415324.004.

21 Makarao, T. (2013). Penerapan Restorative Justice dalam Penyelesaian Tindak Pidana yang dilakukan oleh Anak-Anak. BPHN. 


\subsection{Mediasi sebagai Alternatif Penyelesaian Sengketa dalam Kacamata Hukum Pidana dan Perdata}

Mengacu pada perspektif hukum pidana, Mustafa Serdar Özbek menyatakan bahwa mediasi menjadi prosedur yang fleksibel, komprehensif, problem solver, partisipatif, menekankan pentingnya partisipasi aktif dari orang-orang yang terkena dampak perkara, seperti korban dan pelaku, serta masyarakat. ${ }^{22}$ Manfaat lainnya adalah bahwa mediasi mendorong pelaku untuk merasa bertanggung jawab untuk menyelesaikan rehabilitasi dan memungkinkan integrasi pelaku yang lebih baik kembali ke masyarakat, sehingga memberikan kesempatan praktis untuk memperbaiki kondisi mereka. Berdasarkan uraian tersebut, mediasi merupakan prosedur yang efisien untuk untuk menyelesaikan konflik para pihak.

Penelitian yang dilakukan oleh Andi Sofyan membuktikan bahwa mediasi penal terbukti berhasil menciptakan win-win solution di antara orang-orang yang berperkara, termasuk pelaku pidana di ranah kesehatan. ${ }^{23}$ Penyelesaian secara "win-win solution" dapat memberi kepuasan kepada semua pihak yang berperkara, sebagaimana yang disampaikan oleh Covey dalam Abildanwa bahwa: ${ }^{24}$

Win-Win is a frame of mind and heart that constantly seeks mutual bene $t$ in all human interactions. Win/Win means that agreements or solutions are mutually beneficial, mutually satisfying. With a Win/Win solution, all parties feel good about the decision and feel committed to the action plan. Win/Win sees life as a cooperative, not a competitive arena.

Flora HS dalam penelitiannya menyimpulkan bahwa mediasi penal di Indonesia secara subtantif digali, tumbuh, dan berkembang dari bumi Indonesia melalui kearifan lokal hukum adat serta nilai - nilai Pancasila. ${ }^{25}$ Mediasi penal secara diatur dalam Peraturan dan Surat Kapolri serta Peraturan Menteri secara terbatas dan parsial. Untuk mendukung keberhasilan mediasi penal, diperlukan pembentukan infrastruktur melalui lembaga hukum melaui harmonisasi sistem peradilan pidana sehingga memungkinkan adanya alternatif lain dalam penyelesaian perkara. Untuk mewujudkan upaya tersebut, dibutuhkan sinergi Pemerintah, DPR RI, Mahkamah Agung, Kementerian, Tokoh Agama, Tokoh Adat, Tokoh Masyarakat, Aparat Penegak Hukum (Kepolisian/Kejaksaan) dan Komponen Masyarakat. Peran dari setiap komponen dapat dilakukan sosialisasi, komunikasi, koordinasi, pelatihan, penegakan hukum, dan kurikulum pendidikan tinggi hukum.

Sedangkan, dalam perspektif hukum perdata, dasar hukum mediasi terdapat dalam Pasal 130 HIR dan 149 RBg, dan Pasal 1851 KUHP Perdata yang berisikan tentang

22 Özbek, M. S. (2012). The Principles and Procedure of Penal Mediation in Turkish Criminal Procedure Law. Ankara Law Review, 8(2), 153-220.

23 Sofyan, A. (2015). Penal Mediation in Health Law. Journal of Research in Humanities and Social Science, 3(12), 1-7.

24 Abildanwa, T. (2016). Mediasi Penal Sebagai Upaya Dalam Rangka Pembaharuan Hukum Pidana Di Indonesia Berbasis Nilai-Nilai Keseimbangan. Jurnal Pembaharuan Hukum, III(1), 138-148. doi: http://dx.doi.org/10.26532/jph.v3i1.1353

25 Yusriando. (2015). Implementasi Mediasi Penal Sebagai Perwujudan Nilai- Nilai Pancasila Guna Mendukung Supremasi Hukum Dalam Rangka Pembangunan Nasional. Jurnal Pembaruan Hukum, II(1), 23-45. doi: http:/ / dx.doi.org/10.26532/jph.v2i1.1413 
kewajiban hakim dalam mendamaikan pihak yang bersengketa yang dikemas dalam bentuk mediasi. Mediasi dalam hukum perdata memberi penekanan pada keberadaan pihak ke tiga yang menjembatani para pihak bersengketa sebagai sarana mendamaikan kedua belah pihak. Untuk menyelesaikan sengketa tanah, Badan Pertanahan Nasional dalam prakteknya mengembangkan proses mediasi dalam bentuk penyelesaian sengketa secara sukarela. Fadli Andi Natsif menyatakan bahwa mediasi tersebut terbukti cukup efektif dalam menyelesaikan sengketa dan putusannya diakui oleh para pihak yang bersengketa melalui surat perjanjian kesepakatan perdamaian antara kedua belah pihak. ${ }^{26}$ Khusus untuk penyelesaian sengketa lingkungan hidup, mediasi diatur dalam Peraturan Pemerintah Nomor 54 Tahun 2000 Lembaga Penyedia Jasa Pelayanan Penyelesaian Sengketa Lingkungan Hidup Di Luar Pengadilan. Terdapat perbedaan yang signifikan antara mediasi dan litigasi karena litigasi berpijak pada hasil akhir sesuai dengan hukum yang berlaku. Selain itu, mediasi juga memiliki perbedaan dengan konseling karena landasan mediasi tidak berpijak pada faktor psikologis dan perilaku. Demikian pula mediasi berbeda dengan arbitrase, di mana posisi arbitrer ditunjuk untuk memberikan keputusan akhir. ${ }^{27}$

\subsection{Pranata Yuridis Mediasi sebagai Alternatif Penyelesaian Sengketa Hak Cipta}

Pasal 4 ayat 2 PERMA Nomor 1 Tahun 2016 tentang Prosedur Mediasi di Pengadilan menjelaskan bahwa mediasi bersifat wajib pada semua perkara perdata kecuali sengketa yang dikecualikan dari kewajiban penyelesaian melalui mediasi sebagaimana dimaksud pada ayat (1) meliputi:

a. Sengketa yang pemeriksaannya di persidangan ditentukan tenggang waktu penyelesaiannya meliputi antara lain:

1) Sengketa yang diselesaikan melalui prosedur Pengadilan Niaga;

2) Sengketa yang diselesaikan melalui prosedur Pengadilan Hubungan Industrial;

3) Keberatan atas putusan Komisi Pengawas Persaingan Usaha;

4) Keberatan atas putusan Badan Penyelesaian Sengketa Konsumen;

5) Permohonan pembatalan putusan arbitrase;

6) Keberatan atas putusan Komisi Informasi;

7) Penyelesaian perselisihan partai politik;

8) Sengketa yang diselesaikan melalui tata cara gugatan sederhana; dan

b. Sengketa lain yang pemeriksaannya di persidangan ditentukan tenggang waktu penyelesaiannya dalam ketentuan peraturan perundang-undangan;

1) Sengketa yang pemeriksaannya dilakukan tanpa hadirnya penggugat atau tergugat yang telah dipanggil secara patut;

2) Gugatan balik (rekonvensi) dan masuknya pihak ketiga dalam suatu perkara (intervensi);

3) Sengketa mengenai pencegahan, penolakan,

4) Pembatalan dan pengesahan perkawinan;

5) Sengketa yang diajukan ke pengadilan setelah diupayakan penyelesaian di luar pengadilan melalui mediasi dengan bantuan mediator bersertifikat yang

26 Riolita, R. (2016). Analisis Yuridis Mediasi Penal dalam Penyelesaian Sengketa Tanah terhadap Sertifikat Ganda di Kantor Pertanahan Kota Semarang. Indonesian Journal of Criminal Law Studies, 1(1), 57-75. doi: https://doi.org/10.15294/ijcls.v1i1.10805

27 Wade, J. (2004). Sekitar Mediasi. MARI. 
terdaftar di pengadilan setempat tetapi dinyatakan tidak berhasil berdasarkan pernyataan yang ditandatangani oleh para pihak dan mediator bersertifikat.

Dari ketentuan diatas, terdapat kekaburan norma (vague normen) kewajiban mediasi tersebut dalam Pasal 4 ayat 2 Perma Nomor 1 tahun 2016 yang menyatakan bahwa ada pengecualian kewajiban mediasi salah satunya di pengadilan niaga. Ketentuan ini berpotensi bagi hakim untuk mengesampingkan proses mediasi dalam sengketa Hak Cipta yang didasarkan pada pasal dalam Perma Nomor 1 Tahun 2016.

Penyelesaian sengketa di bidang Hak Cipta sendiri termasuk sengketa yang mewajibkan para pihak untuk mediasi terlebih dahulu. Berdasarkan Pasal 95 ayat (1) UUHC menyebutkan bahwa penyelesaian sengketa Hak Cipta dapat dilakukan secara litigasi dan Alternatif Penyelesaian Sengketa. Penyelesaian sengketa Hak Cipta dapat dilakukan melalui alternative penyelesaian sengketa, arbitrase, atau pengadilan. Namun dalam Penjelasan Pasal tersebut yang dimaksud dengan alternative penyelesaian sengketa adalah proses penyelesaian sengketa melalui mediasi, negosiasi atau konsiliasi.

Selain dalam aturan hukum nasional, dalam tataran hukum Internasional pada Part III Article 41 (1) Trade Related to Intelectual Property Rights (TRIPs) Agreement yang telah diratifikasi oleh Indonesia menyatakan bahwa setiap negara anggota wajib untuk menyediakan mekanisme penegakan hukum HKI berdasarkan hukum nasional yang tidak terlepas dari ketentuan TRIPS. Konsekuensinya, UUHC menjadi instrumen dalam menyelesaikan sengketa Hak Cipta, termasuk penggunaan jalur non-litigasi. Begitu juga sengketa yang terjadi antar negara, maka penyelesaian sengketa dapat ditempuh melalui penyelesaian sengketa pada umumnya, yaitu negosiasi dan mediasi, arbitrase dan litigasi. Secara internasional, World Intellectual Property Organization (WIPO) telah memiliki satu badan arbitrase dan mediasi yaitu WIPO Mediation $\mathcal{E}$ Arbitration Center yang bermarkas di Jenewa, Swiss. ${ }^{28}$

\subsection{Legal Reasoning Penegakan Hukum atas Tindak Pidana Hak Cipta melalui Mediasi}

Terjadinya pelanggaran hak cipta tak lepas dari beberapa faktor yang meliputi. ${ }^{29}$

a. Pelaku menginginkan keuntungan besar dari pelanggaran Hak Cipta;

b. Sanksi hukum yang dibebankan kepada pelaku dianggap terlalu ringan dan tidak ada tindakan pencegahan sebelum pelanggaran dilakukan;

c. Kebanggaan pencipta apabila karyanya ditiru oleh orang lain;

d. Keuntungan atas hilangnya kewajiban membayar pajak; dan

e. Kurangnya kesadaran masyarakat dalam membeli produk asli dengan pertimbangan harga yang murah.

Berdasarkan faktor diatas, penyebab pelanggaran hak cipta tidak lepas dari faktor sosio kultur masyarakat yang penyelesaiannya tidak hanya sekedar diadili melalui

28 Frans Hendra Winarta. (2009). Hukum Penyelesaian Sengketa Arbitrase Nasional Indonesia dan Internasional. Jakarta: Sinar Grafika.

29 Munawar, A., \& Effendy, T. (2016). Upaya Penegakan Hukum Pelanggaran Hak Cipta menurut Undang-Undang Nomor 28 tahun 2014 Tentang Hak Cipta. Al'Adl, VIII(2), 125-137. doi: https:// doi.org/10.1017/CBO9781107415324.004. 
litigasi namun dapat diselesaikan dengan non litigasi melalui mediasi para pihak supaya terwujud solusi yang tepat dan adil bagi kedua belah pihak.

Pengintegrasian mediasi ke dalam proses beracara di Pengadilan memiliki potensi sebagai sarana untuk menyelesaikan sengketa yang lebih ekonomis baik dari sudut pandang biaya maupun waktu. Selain itu, proses mediasi di Pengadilan diharapkan dapat mengatasi masalah penumpukan perkara.

Keberadaan mediasi sebagai Alternatif Penyelesaian Sengketa menjawab kritik terhadap proses litigasi di peradilan yang membutuhkan waktu yang lama, putusan final and binding yang sulit diperoleh, biaya yang tinggi, adanya persepsi bahwa beracara adalah saling melawan antar pihak, putusan yang berdampak pada konflik baru..$^{30}$

Meskipun pada umumnya penyelesaian sengketa di luar pengadilan hanya dalam sengketa perdata, tetapi dalam prakteknya seringkali juga kasus pidana diselesaikan di luar pengadilan dengan diskresi lembaga penegak hukum atau melalui mekanisme konsultasi/lembaga perdamaian atau remisi yang ada di masyarakat. ${ }^{31}$

Penjelasan diatas mengisyaratkan mediasi sangat berperan penting dalam pengembangan penyelesaian sengketa hak cipta yang cenderung lama dan membutuhkan biaya yang banyak. Implikasi mediasi dalam penyelesaian sengketa hak cipta dapat dilihat dari beberapa faktor/alasan sebagai berikut:

\section{a. Mediasi sebagai Solusi Biaya Litigasi Hak Cipta yang Relatif Mahal}

Perkembangan teknologi membuat produk intelektual yang dilindungi Hak Cipta dapat tersebar luas di dunia dalam hitungan detik. Fenomena ini berpotensi menimbulkan pelanggaran Hak Cipta yang semakin massif, bahkan keluar dari yurisdiksi Indonesia. Tidak bisa dibayangkan apabila pemilik Hak Cipta tersebut melakukan aksi represif Indonesia, maka jumlah pihak - pihak yang terkena gugatan dan sanksi pidana akan sangat besar dan biaya yang ditimbulkan dari sengketa tersebut cukup tinggi. Sebagai perbandingan, menurut riset yang dilakukan oleh Stephen Anway, biaya rata-rata dari gugatan pelanggaran hak cipta $\$ 200.000$ melalui persidangan. Selanjutnya, biaya gugatan pelanggaran hak cipta semakin meningkat yang linear dengan peningkatan kebutuhan untuk menggunakan saksi ahli dan kompleksitas masalah. Sebaliknya, biaya rata-rata mediasi adalah $\$ 50.000$, lebih rendah dari litigasi hak cipta dan bentuk penyelesaian sengketa alternatif lainnya.

Tingginya biaya litigasi hak cipta juga diperburuk oleh disposisi kasus-kasus hak cipta yang terlalu lama dan memakan waktu. Pengacara kekayaan intelektual sering ingin mengambil kasus biaya kontingensi karena biaya dan sifat litigasi Hak Cipta yang memakan waktu. Seperti yang dicatat oleh Blackman and McNeill bahwa mediasi menjadi solusi untuk mengurangi biaya mahal dan ekstensif dari litigasi karena

30 Soetrisno, S. (2010). Malpraktik Medik dan Mediasi Sebagai Alternative Penyelesaian Sengketa. Tanggerang: Telaga Ilmu.

31 Flora, H. (2015). Penal Mediation As An Alternative Model of Restorative Justice in The Criminal Justice System of Children. International Journal of Business, Economics and Law, 6(4), 6-10. 
masalah-masalah yang akan ditemukan dipersempit pada awal proses..$^{32}$ Selain itu, prospek mediasi dapat mendorong pengacara atau firma hukum untuk mengambil kasus hak cipta sebagai kemungkinan resolusi yang lebih cepat dapat mengizinkan lebih banyak pengacara atau firma untuk mengakomodasi penggugat individu dengan biaya kontingensi dan rencana biaya lainnya.

Biaya yang tinggi dalam proses penyelesaian sengketa hak cipta melalui pengadilan sebenarnya bertolak belakang dengan keinginan dari pencipta yang dirugikan akibat hak ekonominya dilanggar. Artinya bisa jadi pencipta tidak menemui keadilan yang diharapkan justru malah dirugikan dengan pengenaan biaya yang tinggi dalam penyelesaian perkara.

\section{b. Mediasi Meringankan Kerja Hukum Acara}

Menurut Thornas J.Harron, masyarakat sudah jemu dengan penyelesaian sengketa melalui litigasi dengan beberapa faktor, yaitu ketidakpuasan mereka atas system peradilan yang bertele-tele yang justru merugikan dan menghabiskan banyak waktu. Selain mekanisme dan sistem peradilan yang tidak memuaskan, faktor yang menyebabkan beralihnya pilihan ke ADR adalah biaya peradilan yang mahal, permasalahan yang dibahas adalah masa lalu buka kepada cara untuk menyelesaikan masalah di masa depan yang tentunya hal tersebut berimbas kepada permusuhan para pihak, bahkan cenderung membuat salah satu pihak lumpuh, artinya jalur litigasi bukan kepada upaya perbaikan. Lebih jauh lagi, hakim yang menguasai HKI masih sangat minim, mengingat pengaturan HKI yang kompleks, sedangkan penyelesaian hak cipta melalui mediasi memberikan peluang bagi pihak yang bersengketa untuk membuat kesepakatan dengan menunjuk pihak ketiga diluar hakim yang dipilih berdasarkan keahliannya.

Meskipun hasil penyelesaian yang diambil dalam proses ADR bukan res judicata (putusan pengadilan), namun menurut Robert N. Codey dan O.Lee Reed dalam bukunya Fundamentals of the Environment Of Business, ternyata masyarakat cenderung memilih ADR atas alasan "much quicker, no delay, and less expensive" dibandingkan jalur litigasi. Jika berangkat dari pendapat-pendapat tentang ketidakpuasan masyarakat terhadap proses litigasi yang banyak merugikan, maka urgensi mediasi dalam penyelesaian sengketa hak cipta adalah sesuatu yang dikehendaki oleh masyarakat.

Alasan lain mengenai urgensi mediasi dalam kasus hak cipta adalah ketidaktahuan masyarakat mengenai hak cipta itu sendiri, mulai dari hal-hal yang prinsip dalam HKI. Misalnya seniman masih belum bisa membedakan antara ciptaan, karya cipta, hak cipta dan pencipta. Sehingga jika sengketa dilanjutkan ke proses litigasi mereka tidak bisa memahami hak-hak mereka sendiri. Ketidakpahaman tersebut berpotensi membahayakan dirinya sendiri. Karena bisa jadi seniman dan masyarakat berpotensi menjadi korban atau pelaku pelanggaran HKI khususnya Hak Cipta. ${ }^{33}$

32 BlackMann, S. H., \& McNeill, R. M. (1998). Alternative Dispute Resolution in Commercial Intellectual Property Disputes. American Univerity Law Review, 47, 1709-1734.

33 Achmad Zen Umar Purba. (2013). Arbitrase dan Mediasi HKI Belum Dilirik. Hukum Online. https://www.hukumonline.com/berita/baca/lt5118dd47bc07e/arbitrase-dan-mediasi-hkibelum-dilirik/?page=all 
Dalam praktiknya, sengketa atau pelanggaran hak cipta bagi pihak yang dilanggar hak ciptanya akan lebih memilih ganti rugi ketimbang sanksi pidana atau denda. Oleh karena landasan tersebut muncul ide alternatif penyelesaian sengketa Hak Cipta melalui mediasi dalam UU Hak Cipta yang baru ketimbang langsung melalui Pengadilan.

\section{c. Mediasi sebagai "Solusi Alternatif berbagi Hak Cipta"}

Jargon "Hukum selalu tertinggal selangkah di belakang teknologi" terbukti dalam kasus Hak Cipta. Situs berbagi file (file sharing) seperti Napster melalui websitenya mp3.com digugat oleh A\&M Records karena merancang dan mengoperasikan jaringan berbagi file peer-to-peer (P2P) yang memungkinkan pengguna untuk mencari, mengakses, dan mengunduh rekaman audio yang disimpan dalam format file digital MP3 di komputer mereka sendiri atau orang lain. A\&M Records mengeluh bahwa pengguna Napster memperoleh karya berhak cipta dari komputer jaringan masingmasing tanpa izin pemegang hak cipta. Napster menegaskan bahwa layanan tersebut memiliki tujuan yang sah yaitu pengambilan lagu yang berfungsi dalam memutuskan apakah akan melakukan pembelian; mengakses karya-karya yang sudah dimiliki pengguna (pemindahan ruang); dan menerima distribusi resmi karya berhak cipta. Penggugat menuduh Napster bertanggung jawab atas pelanggaran hak cipta yang mengakibatkan kerugian pada penggugat. Pengadilan distrik memberikan perintah awal kepada penggugat, dan menemukan bahwa layanan berbagi file Napster bukanlah penggunaan yang wajar atas karya berhak cipta.

Sebagai contoh lain, industri streaming music seperti spotify memberikan kompensasi sebesar $70 \%$ kepada pemegang hak industri music streaming seperti spotify bersamasama dengan industri music streaming pada umumnya dengan membayar seniman berdasarkan pangsa pasar mereka (jumlah aliran lagu mereka sebagai proporsi dari total lagu streaming pada layanan). Mereka mendistribusikan sekitar $70 \%$ untuk pemegang hak, yang kemudian akan membayar seniman berdasarkan perjanjian masing-masing. Sampel kasus diatas dapat menjadi rekomendasi dalam penyelesaian sengketa hak cipta melalui mediasi yang bertujuan untuk berbagi karya. Hal tersebut menegaskan bahwa proses penyelesaian sengketa hak cipta melalui litigasi yang sebelumnya lebih dominan dilakukan, tidak sesuai dengan semangat restorative justice.

Contoh masalah yang dapat berdampak buruk pada potensi pemulihan penggugat adalah apakah (dan kapan) suatu karya tercatat di Kementerian Hukum dan HAM cq Ditjen Hak Kekayaan Intelektual (Ditjen HKI). Meskipun pendaftaran suatu karya tidak diperlukan untuk mengamankan perlindungan hak cipta namun pencatatan karya ciptaan tersebut dapat dijadikan sebagai salah satu alat bukti surat sebagaimana dalam Hukum Acara Perdata. Direktur Intellectual Property Advisory Services (IPAS) Dwiyanto Prihartono mengatakan bahwa pembuktian dalam perkara Hak Cipta sangat kompleks yang berkaitan dengan penyediaan alat bukti. Pada praktiknya, alat bukti yang dihadirkan di persidangan bukan merupakan dokumen resmi sehingga hakim seringkali kesulitan dalam menemukan orisinalitas karya cipta dari para pihak.

Kasus Ismail Hutajulu vs PT Lolypop Records tahun 1990 menjadi salah satu sorotan karena kala itu Mahkamah Agung (MA) menolak gugatan yang diajukan oleh Ismail dengan alasan bahwa Ismail hanya menghadirkan bukti berupa coretan tanpa arti karena tidak diberi tanggal dan tanda tangan. Dengan demikian, Pencipta dan 
pemegang Hak Cipta dibiarkan dalam kesulitan sehingga berdampak pada biaya litigasi yang besar. Lebih jauh lagi, kegagalan dalam pembuktian kepemilikan Hak Cipta berarti mengizinkan pelanggar untuk melakukan perbuatannya lebih jauh. Adanya mediasi dapat digunakan sebagai forum di mana karya-karya tersebut dapat "dibagikan," dan pilihan yang berharga bagi Pencipta jika tidak mengetahui kapan dan dimana penciptaan dilakukan.

\section{d. Mediasi sebagai sarana Membangun Jejaring dan Reputasi Bisnis}

Lamanya proses litigasi acapkali menimbulkan gangguan terhadap operasi bisnis, terutama pada pihak - pihak yang berprofesi sebagai pelaku usaha. Selain itu, perselisihan antar pelaku usaha dalam Hak Cipta juga dapat menimbulkan hubungan bisnis yang memburuk. Sebagai contoh, penulis mengasumsikan bahwa hubungan bisnis antara para pihak yang bersengketa menguntungkan di masa lalu. Dengan munculnya sengketa melalui proses litigasi berpotensi merusak reputasi masingmasing pihak dan mengakhiri hubungan baik diantara mereka. Dampak akhirnya adalah bertambahnya kerugian yang diderita apabila kalah dalam persidangan. Untuk pelaku bisnis seperti distributor, dilema diperburuk karena produsen tersebut adalah produsen terkenal yang mendominasi produk tertentu dan mendominasi pasar. Bagi produsen, situasinya semakin sulit dengan reputasi distributor yang tak tergantikan di pasar.

Sebagai cara untuk menghindari kerusakan hubungan tersebut, mediasi memberi para pihak suatu proses untuk menyelesaikan perselisihan secara damai. Keinginan para pihak yang mengalami perselisihan Hak Cipta untuk menjaga hubungan bisnis mereka. Kondisi ini juga dapat muncul dalam berbagai situasi lain, seperti dalam konteks perjanjian waralaba yang ada atau perjanjian lisensi bernilai yang tidak terkait dengan perselisihan. Apapun kondisinya, mediasi menawarkan kepada pihak hak cipta sebuah kemampuan untuk melestarikan dan dapat memperkuat hubungan dan reputasi bisnis mereka.

\section{e. Kehendak Pancasila dalam Mendamaikan Pihak yang Bersengketa}

Hak Cipta memiliki peranan strategis dalam mendukung pembangunan bangsa dan memajukan kesejahteraan umum sebagaimana diamanatkan oleh Undang-Undang Dasar Negara Republik Indonesia Tahun $1945 .{ }^{34}$ Berdasarkan data yang diperoleh penulis, tercatat bahwa aplikasi Hak Cipta berdampak pada pertumbuhan ekonomi melalui Pendapatan Negara Bukan Pajak (PNBP), data Ditjen HKI menunjukkan bahwa Pendapatan Negara Bukan Pajak (PNBP) dari pencatatan Hak Cipta sampai dengan tahun 2018 sebesar 12,5 Milyar rupiah. ${ }^{35}$

Pancasila sebagai dasar negara merupakan landasan yang memiliki kekuatan yuridis konstitusional. Kelima sila dalam Pancasila dituangkan dalam pembukaan UUD NRI 1945 yang artinya kedudukan Pancasila sebagai staatfundamentalnorm atau pokok

34 Margono, S. (2015). Prinsip Deklaratif Pendaftaran Hak Cipta. Rechtsvinding, 1(2), 237-255. doi: http://dx.doi.org/10.33331/rechtsvinding.v1i2.99.

35 Bagus Edhita Praja, C., Sulistyaningsih, P., Agus Riswandi, B., \& Mulyadi. (2020). Strengthening Waqf Institution To Develop Intellectual Property As a Waqf Asset. Humanities $\mathcal{E}$ Social Sciences Reviews, 8(3), 610-617. doi: https://doi.org/10.18510/hssr.2020.8365. 
kaidah negara yang fundamental. ${ }^{36}$ Pancasila diposisikan sebagai citra hukum bangsa Indonesia, sehingga seluruh batang tubuh UUD maupun aturan perundang-undangan di bawahnya harus disesuaikan dengan nilai-nilai Pancasila, karena Pancasila sebagai sumber nilai falsafah bangsa atau nilai kebenaran dan keadilan bagi bangsa Indonesia. ${ }^{37}$ Pancasila selain sebagai sumber hukum juga sebagai sumber moral berbangsa. Artinya peraturan perundang-undangan dapat dikategorikan memenuhi keadilan bagi masyarakat jika isinya berdasarkan Pancasila dan tidak bertentangan dengan kelima sila tersebut. Dengan demikian cita hukum suatu bangsa adalah tolak ukur penentuan kesejahteraan dan keadilan dalam suatu bangsa itu dengan memperlihatkan nilai-nilai yang tumbuh dalam masyarakat serta tidak memperlihatkan nilai yang condong ke ciri liberal ataupun sosialis namun Pancasila sebagai jalan tengah atau nilai prismatik. ${ }^{38}$

Nilai-nilai prismatik dalam Pancasila yang menempatkan tidak berdasarkan Ideologi liberal maupun sosialis menjadi pilihan serta memiliki ciri khas bagi Negara Hukum Pancasila di Indonesia. Konsep prismatik dalam sistem hukum nasional Indonesia bermakna Negara hukum Pancasila adalah jalan tengah antara kepentingan individualism dan kolektivisme. Pancasila dan UUD NRI 1945 mengakui hak-hak (termasuk hak milik) dan kebebasan individu sebagai hak asasi, tetapi sekaligus meletakkan kepentingan bersama di atas kepentingan pribadi. ${ }^{39}$

Penyelesaian dengan jalan damai antara pelanggar dan korban dalam bidang Hak Cipta berdasarkan hubungan privat to privat (privaaatrechtelijk). Secara filosofis, mediasi sebagai salah satu alternatif penyelesaian dilandaskan atas nilai pada Pancasila. Pertama, bahwa mediasi merupakan salah satu bentuk dari pengamalan Sila ke empat bahwa mengutamakan musyawarah demi mewujudkan kepentingan bersama. Kedua, Sila kelima bahwa suatu keadilan adalah suatu keadilan dalam hidup bersama. Hakikat keadilan Pancasila tercermin dalam pengakuan dan perlakuan setiap orang sebagaimana manusia artinya keadilan yang mencerminkan hubungan antar manusia, yakni Justitia Commutativia atau norma yang mengatur hubungan antar pribadi. Justitia distibutiva atau norma yang menentukan kewajiban masyarakat untuk mensejahterakan individu dan Justitia legalis yang menunjukan norma yang menentukan kewajiban individu terhadap masyarakat. ${ }^{40}$

Sebagai hak privat, pelaksanaan mediasi sebelum ke jalur litigasi merupakan pengamalan dari nilai Pancasila, terutama untuk pemenuhan keadilan bagi kedua belah pihak karena dalam hak privat tidak ada kepentingan publik yang dilanggar, kecuali dalam hal pembajakan. Hasil kesepakatan dalam mediasi pun dapat bervariasi sesuai dengan kesepakatan dan nilai musyawarah masyarakat Indonesia.

\section{f. Pelaksanaan Mediasi Sengketa Hak Cipta Sebagai Budaya Hukum}

36 Natsif, F. A. (2017). Pancasila Dalam Perspektif Hukum Konstitusi Indonesia. Jurisprudentie, 4(2), 122. doi: https:// doi.org/10.24252/jurisprudentie.v4i2.4057.

37 Mertokusumo, \& Sudikno. (2007). Mengenal Hukum Suatu Pengantar. Yogyakarta: Liberty.

38 Zainuddin Ali. (2006). Filsafat Hukum. Jakarta: Sinar Grafika.

39 Moh. Mahfud MD. (2011). Penuangan Pancasila Dalam Peraturan Perundang-undangan. In Mahkamah Konstitusi. Universitas Gadjah Mada.

40 Soerjanto Poespowardojo. (1989). Filsafat Pancasila: Sebuah Pendekatan Sosio-Budaya. Jakarta: Balai Pustaka. 
Menurut Satjipto Raharjo, budaya hukum adalah kekuatan yang ada dalam masyarakat yang berakar kepada sistem nilai dan tradisi yang dianut, yang kemudian menentukan bagaimana hukum tersebut dapat diterima dan dapat dilaksanakan di masyarakat. Faktor tradisi dan sistem nilai yang dianut menentukan bagaimana hukum itu diterima dan dilaksanakan. ${ }^{41}$ Mediasi merupakan upaya penyelesaian sengketa Hak cipta yang berakar dari budaya masyarakat Indonesia dengan mengedepankan musyawarah mufakat. Untuk itu, upaya pembangunan budaya hukum mediasi hak cipta di tengah banyaknya pelanggaran dan beragam kreativitas harus dapat diterima masyarakat Indonesia. Pemberlakuan budaya mediasi dalam sengketa hak cipta harus diiringi dengan pembangunan substansi dan struktur hukum secara bersamaan sebagai prasyarat terciptanya sistem hukum sebagaimana dijelaskan dalam teori sistem hukum Friedman. ${ }^{42}$

Secara struktur, Indonesia telah memiliki Badan Arbitrase dan Mediasi Hak Kekayaan Intelektual (BAM HKI) yang dibentuk pada tahun 2011. Kemunculan BAM HKI ini bertujuan untuk: ${ }^{43}$

1) Melakukan penyelesaian sengketa secara adil dan cepat terhadap perkara yang bersifat adjudikatif di bidang HKI

2) Melaksanakan pelatihan, Pendidikan dan sosialisasi di bidang HKI yang relevan dengan maksud dan tujuan BAM HKI

3) Melaksanakan kegiatan lain yang berkaitan dengan arbitrase dan mediasi yang tidak bertentangan dengan kegiatan utama.

Berkembangnya beberapa lembaga arbitrase dan mediasi merupakan sebuah pertanda akan kebutuhan sarana penyelesaian sengketa alternatif dalam menciptakan keadilan terkait dengan sengketa Hak kekayaan intelektual.

Upaya mediasi seharusnya dilakukan oleh masyarakat sebagai langkah awal sebelum melakukan gugatan ke pengadilan sebagai bentuk cerminan nilai musyawarah mufakat. Masyarakat harus diupayakan untuk memahami bahwa mediasi merupakan sebuah forum yang ditengahi oleh seseorang yang netral dan imparsial.

Jika putusan pengadilan tidak mampu memberi rasa keadilan dan kepastian hukum, maka tentu ada yang salah dalam sistem tersebut. Bisa saja hukum tertulis atau para penegak hukum dalam hal ini hakim, belum memahami antara peranan hukum dan gejala keinginan masyarakat. Sebagaimana dikemukakan oleh Pound, bahwa hukum perlu ditempatkan pada persepsi yang telah disepakati bersama untuk memahami hakikat, sifat serta konsekuensi. Dengan demikian selalu terdapat gejala bahwa antara hukum dan perilaku sosial terdapat suatu jarak perbedaan yang sangat mencolok karena tidak adanya pemahaman atas sesuatu yang dikehendaki bersama. Jika hal tersebut terus terjadi maka akan timbul ketegangan yang semestinya harus segera disesuaikan supaya tidak menimbulkan ketegangan yang menganggu kehidupan individu masyarakat secara berkelanjutan. Teori Pound tersebut menegaskan bahwa hukum yang mengedepankan kemaslahatan dan kepentingan masyarakat merupakan

41 Rahardjo, S. (2008). Membedah Hukum Progresif. Jakarta: Kompas Media Nusantara.

42 Lawrence M Friedman. (1984). What is a Legal System. Ner York: W.W Norton and Company.

43 Tampongangoy, G. H. (2015). Arbitrase Merupakan Upaya Hukum dalam Penyelesaian Sengketa Dagang Internasioanal. Lex Et Societatis, 3(1). 160-169. doi: https://doi.org/10.35796/les.v3i1.7081 
sebuah usaha yang lebih eksplisit untuk mengembangkan suatu model hukum responsif. Karena hukum yang baik seharusnya memberikan sesuatu yang lebih daripada sekadar prosedur hukum. ${ }^{44}$

Meski pada awalnya pihak yang bersengketa dalam Hak Cipta belum melirik ke arah ADR terutama mediasi, namun saat ini model-model arbitrase sudah mulai dilirik dan banyak diminati oleh kalangan dunia industri dan pelaku bisnis dalam menyelesaikan sengketa kekayaan intelektual. WIPO Mediation $\mathcal{E}$ Arbitration Center, sebagai contoh, sudah banyak menyelesaikan kasus yang berkaitan dengan perselisihan mengenai kekayaan intelektual seperti artis film Julia Roberts yang terkena sengketa pelanggaran Hak Cipta. Dan para pihak tersebut tunduk pada putusan yang dibuat oleh WIPO Mediation $\mathcal{E}$ Arbitration Center. Di Indonesia sendiri belum bisa dicatat seberapa banyak penyelesaian sengketa tentang hak kekayaan intelektual yang menggunakan sarana BAM HKI, karena dugaan ketidaktahuan para pencipta atau pelaku seni dengan penyelesaian sengketa hak cipta melalui mediasi. Jika saja penggunaan sarana BAM HKI dapat efektif, maka akan lebih menghemat biaya.

\section{g. Perlunya Upaya Peningkatan Peran Mediator dalam Sengketa Hak Cipta}

Dalam bentuk mediasi klasik, mediator mengambil peran fasilitator semata, menahan diri untuk tidak menyisipkan pandangan, nilai, atau solusi ke dalam proses negosiasi. Namun demikian, meningkatnya peran pengacara dan hakim sebagai mediator barubaru ini telah menyebabkan mediasi menjadi lebih efektif dan evaluatif. Teknik evaluatif semacam itu sangat cocok untuk kasus-kasus kekayaan intelektual, karena mereka sering menantang sistem hukum dengan sifat teknisnya yang rumit.

Efektivitas dalam proses penyelesaian sengketa melalui mediasi juga sangat bergantung pada peran mediator. Mediator seharusnya pro aktif dalam menjembatani untuk menghasilkan kesepakatan antara kedua belah pihak yang bersengketa, mengarahkan dan mengendalikan proses, memastikan kelanjutan, dan mendesak para pihak untuk mencapai kesepakatan yang win-win solution. Mediator merupakan pihak ketiga yang tidak memihak yang mewakili kepentingan pihak-pihak yang berkonflik. Kemudian, mediator juga harus memiliki kemampuan menjembatani dan menyelidiki kepentingan para pihak serta dapat memberikan pilihan untuk mencapai tujuan tersebut ${ }^{45}$

Untuk mencapai sebuah kesepakatan, mediator secara progresif mengeksplorasi berbagai strategi penyelesaian. Beberapa tanggung jawab mediator diantaranya: ${ }^{46}$

1) Membangun dan menjaga kepercayaan pihak yang bersengketa

2) Mengedukasi para pihak tentang proses dan komunikasi selama mediasi untuk menjaga iklim yang positif.

3) Membantu pihak untuk menyesuaikan diri dengan keadaan atau kenyataan

4) Mendidik para pihak tentang proses dan seni bernegosiasi

44 Nonet, P., \& Selznick, P. (2003). Hukum responsif pilihan di masa transisi. Jakarta : Perkumpulan untuk Pembaharuan Hukum Berbasis Masyarakat dan Ekologis (HuMa)

45 Karmuji. (2016). Peran Dan Fungsi Mediator Dalam Penyelesaian Perkara Perdata. Jurnal Ummul Qura, VII(1), 36-52.

46 Sudjana, S. (2021). Makna Mediasi Dalam Undang-Undang Nomor 28 Tahun 2014 Tentang Hak Cipta. Veritas et Justitia, 7(1), 91-114. doi: https://doi.org/10.25123/vej.v7i1.3716. 
5) Membantu pihak-pihak dalam memperoleh informasi penting; dan

6) Mengembangkan solusi untuk mempromosikan penyelesaian masalah

Dalam kasus mediasi evaluatif, para pihak dapat mengambil manfaat dari kemampuan mediator hak cipta untuk memperkirakan nilai kasus suatu pihak atau mengevaluasi kemungkinan keberhasilan suatu pihak di persidangan. Pihak-pihak dalam sengketa Hak Cipta juga dapat memilih mediator evaluatif dengan latar belakang perusahaan untuk menyarankan solusi bisnis kreatif yang mungkin diabaikan. Dengan cara ini, mediasi memberi para pihak kesempatan untuk memilih pihak ketiga yang netral berdasarkan pengalaman, pendidikan, dan gaya mediasi. Mediator dalam hal ini harus memperhatikan dengan seksama untuk mendefinisikan apa yang merupakan persyaratan mediasi. Mediator juga harus visioner dan peduli dengan potensi sengketa pasca mediasi.

\section{Kesimpulan}

Berdasarkan argumentasi yang telah dibangun diatas, ada beberapa faktor yang patut untuk dipertimbangkan sebagai alasan memilih mediasi dalam sengketa Hak Cipta. Faktor tersebut adalah 1) Proses litigasi yang memakan biaya yang tinggi (2) Mediasi merupakan solusi alternatif berbagi hak cipta (3) Mediasi sebagai sarana membangun jejaring dan reputasi Bisnis (4) Sulitnya pembuktian dalam sengketa Hak Cipta (5) Kehendak Pancasila dalam penyelesaian pertikaian secara damai (5) litigasi dapat merusak hubungan bisnis atau reputasi para pihak; (6) Mediasi memperingan kerja hukum acara; (7) Mediasi sebagai budaya hukum di Indonesia. Faktor-faktor ini harus dievaluasi dalam konteks apakah mediasi merupakan kepentingan para pihak yang bersengketa. Dengan demikian, perlu dikembangkan tentang konsep yang terkandung dalam penyelesaian perkara di luar pengadilan yaitu: (1) Seorang Mediator yang handal dalam penanganan konflik. Dalam hal ini mediator harus mampu meyakinkan mereka yang terlibat konflik dengan mengedepankan proses komunikasi. (2) Harmonisasi Perma Nomor 1 tahun 2016 dengan UU Hak Cipta dengan mensinkronkan pengecualian kewajiban mediasi di Pengadilan Niaga dengan kewajiban mediasi dalam UU Hak Cipta. (3) Proses Mediasi harus bersifat informal. Dalam proses mediasi diupayakan menghindari adanya pembicaraan yang bersifat formal, sehingga para pihak yang terlibat merasa saling di hargai dan tidak ada ketegangan yang memacu amarah. Implikasi dari proses informal ini adalah terbangunnya jejaring dan reputasi bisnis para pihak.

\section{Daftar Pustaka}

Buku

Dwirachma, F., \& Prastyo, B. A. (2015). Analisis Yuridis terhadap Sengketa Hak Cipta Film Soekarno (Issue 1). Universitas Indonesia.

Frans Hendra Winarta. (2009). Hukum Penyelesaian Sengketa Arbitrase Nasional Indonesia dan Internasional. Jakarta: Sinar Grafika.

Lawrence M Friedman. (1984). What is a Legal System. New York: W.W Norton and Company.

Makarao, T. (2013). Penerapan Restorative Justice dalam Penyelesaian Tindak Pidana yang dilakukan oleh Anak-Anak. BPHN.

Mertokusumo, \& Sudikno. (2007). Mengenal Hukum Suatu Pengantar. Yogyakarta: 
Liberty.

Moh. Mahfud MD. (2011). Penuangan Pancasila Dalam Peraturan Perundangundangan. In Mahkamah Konstitusi. Universitas Gadjah Mada.

Nonet, P., \& Selznick, P. (2003). Hukum responsif pilihan di masa transisi. Jakarta : Perkumpulan untuk Pembaharuan Hukum Berbasis Masyarakat dan Ekologis (HuMa)

Rahardjo, S. (1983). Masalah Penegakan Hukum. Bandung: Sinar Baru.

Rahardjo, S. (2008). Membedah Hukum Progresif. Jakarta: Kompas Media Nusantara

Soerjanto Poespowardojo. (1989). Filsafat Pancasila: Sebuah Pendekatan Sosio-Budaya. Jakarta: Balai Pustaka.

Soetrisno, S. (2010). Malpraktik Medik dan Mediasi Sebagai Alternative Penyelesaian Sengketa. Tanggerang: Telaga Ilmu.

Wade, J. (2004). Sekitar Mediasi. MARI.

Winata, F. H. (2012). Hukum Penyelesaian Sengketa Arbitrase Nasional Indonesia dan Internasional, Jakarta: Sinar Grafika.

Zainuddin Ali. (2006). Filsafat Hukum. Jakarta: Sinar Grafika.

Jurnal

Abildanwa, T. (2016). Mediasi Penal Sebagai Upaya Dalam Rangka Pembaharuan Hukum Pidana Di Indonesia Berbasis Nilai-Nilai Keseimbangan. Jurnal Pembaharuan Hukum, III(1), 138-148. doi: http://dx.doi.org/10.26532/jph.v3i1.1353

Bagus Edhita Praja, C., Sulistyaningsih, P., Agus Riswandi, B., \& Mulyadi. (2020). Strengthening Waqf Institution To Develop Intellectual Property As a Waqf Asset. Humanities $\mathcal{E}$ Social Sciences Reviews, 8(3), 610-617. doi: https:// doi.org/10.18510/hssr.2020.8365

BlackMann, S. H., \& McNeill, R. M. (1998). Alternative Dispute Resolution in Commercial Intellectual Property Disputes. American Univerity Law Review, 47, 1709-1734.

Bunker, M. D., \& Erickson, E. (2019). Transformative Variations: The Uses and Abuses of The Transformative Use Doctrine in Right of Publicity Law. Washington Journal of Law, Technology \& Art, 14(2), 139-159.

Flora, H. (2015). Penal Mediation As An Alternative Model of Restorative Justice in The Criminal Justice System of Children. International Journal of Business, Economics and Law, 6(4), 6-10.

Herawati, N. (2011). Implikasi Mediasi Dalam Perkara Perdata Di Pengadilan Negeri Terhadap Asas Peradilan Sederhana, Cepat, Dan Biaya Ringan. Perspektif, 16(4), 227-235. doi: http:/ / dx.doi.org/10.30742/ perspektif.v16i4.85227-235.

Karmuji. (2016). Peran Dan Fungsi Mediator Dalam Penyelesaian Perkara Perdata. Jurnal Ummul Qura, VII(1), 36-52.

Kurniawaty, Y. (2017). Efektivitas Alternatif Penyelesaian Sengketa (Alternative Dispute Resolution on Intellectual Property Dispute). Jurnal Legislasi Indonesia, 14(2), 163-170. doi: https:/ / doi.org/10.54629/jli.v14i2.98

Margono, S. (2015). Prinsip Deklaratif Pendaftaran Hak Cipta. Rechtsvinding, 1(2), 237- 
255. doi: http://dx.doi.org/10.33331/rechtsvinding.v1i2.99

Munawar, A., \& Effendy, T. (2016). Upaya Penegakan Hukum Pelanggaran Hak Cipta menurut Undang-Undang Nomor 28 tahun 2014 Tentang Hak Cipta. Al'Adl, VIII(2), 125-137. doi: https:// doi.org/10.1017/CBO9781107415324.004

Natsif, F. A. (2017). Pancasila Dalam Perspektif Hukum Konstitusi Indonesia. Jurisprudentie, 4(2), 122. doi: https:/ / doi.org/10.24252/jurisprudentie.v4i2.4057

Nugrahani, R. A. G. (2018). Pelanggaran Hak Cipta Sebagai Dampak Perkembangan Teknologi. Hukum Pidana Dan Pembangunan Hukum, 1(1), 1-6.

Özbek, M. S. (2012). The Principles and Procedure of Penal Mediation in Turkish Criminal Procedure Law. Ankara Law Review, 8(2), 153-220.

Riolita, R. (2016). Analisis Yuridis Mediasi Penal dalam Penyelesaian Sengketa Tanah terhadap Sertifikat Ganda di Kantor Pertanahan Kota Semarang. Indonesian Journal Of Criminal Law Studies, 1(1), 57-75. doi: https://doi.org/10.15294/ijcls.v1i1.10805

Rosenblatt, E. (2019). Fair Use As Resistance. SSRN Electronic Journal, 9(2), 377-400. doi: https://doi.org/10.2139/ssrn.3348551

Sofyan, A. (2015). Penal Mediation in Health Law. Journal of Research in Humanities and Social Science, 3(12), 1-7.

Sudjana, S. (2018). Implikasi Doktrin "Fair Use" Terhadap Pengembangan Ilmu Pengetahuan Oleh Akademisi (Dosen) Atau Peneliti Dalam Perspektif Hukum Hak Cipta. Veritas et Justitia, 4(2), 493-514. doi: https://doi.org/10.25123/vej.2993.

Sudjana, S. (2021). Makna Mediasi Dalam Undang-Undang Nomor 28 Tahun 2014 Tentang Hak Cipta. Veritas et Justitia, 7(1), 91-114. doi: https://doi.org/10.25123/vej.v7i1.3716

Sulardi, \& Wardoyo, Y. P. (2015). Kepastian Hukum, Kemanfaatan, dan Keadilan terhadap Perkara Pidana Anak (Kajian Putusan Nomor 201/Pid.Sus/2014/PN.Blt). Jurnal Yudisial, 8(3), 251-268. doi: https:/ / doi.org/10.1017/CBO9781107415324.004

Tampongangoy, G. H. (2015). Arbitrase Merupakan Upaya Hukum dalam Penyelesaian Sengketa Dagang Internasioanal. Lex Et Societatis, 3(1). 160-169. doi: https:// doi.org/10.35796/les.v3i1.7081

Taufikkurahman. (2015). Alternative Dispute Resolution dalam Penyelesaian Sengketa Konsumen. Iqtishadia, 2(1), 22-43. doi: https://doi.org/10.19105/iqtishadia. v2i1.837.

Wibawa, D. G. Y. P., \& Krisnawati, I. G. A. A. A. (2019). Upaya Mediasi Dalam Penyelesaian Sengketa Pelanggaran Hak Cipta. Jurnal Kertha Wicara, Fakultas Hukum Universitas Udayana, 8(01).1-15. https://ocs.unud.ac.id/index.php/ kerthawicara/article/download/45751/27761

Yusriando. (2015). Implementasi Mediasi Penal Sebagai Perwujudan Nilai- Nilai Pancasila Guna Mendukung Supremasi Hukum Dalam Rangka Pembangunan Nasional. Jurnal Pembaruan Hukum, II(1), 23-45. doi: http:/ / dx.doi.org/10.26532/jph.v2i1.1413 


\section{Internet}

Achmad Zen Umar Purba. (2013). Arbitrase dan Mediasi HKI Belum Dilirik. Hukum Online.

A.Haryo Yudanto, SH, MH, B. (2018). Memberdayakan Mediasi: Musyawarah untuk Mufakat. https://jdih.bappenas.go.id/data/file/Memberdayakan_Mediasi_ musyawarah_mufakat.pdf

BBC. (2010). RI pelanggar terburuk HKI di Asia. BBC.

DJKI. (2019). Permohonan dan Pelindungan HKI di Indonesia 2015-2019.

Pro Kontra Pembentukan Arbitrase Dan Mediasi HKI. https://www.hukumonline.com/berita/baca/lt4c05244b2baae/pro-kontrapembentukan-arbitrase-dan-mediasi-hki/

Sindo. (2016). Indonesia Lemah soal Perlindungan Kekayaan Intelektual. SINDO.

USTR. (2017). 2017 Special 301 Report. https://ustr.gov/sites/default/files/301/2017 \%20Special\%20301\%20Report\%20FINAL.PDF

\section{Peraturan Perundang-Undangan}

Undang Undang Nomor 28 Tahun 2014 tentang Hak Cipta, Pub. L. No. 28 (2014). 